explain to the rest of the world since the controversial nuclear deal with West Germany in 1975: that Brazil, which is poor in oil, has low-grade coal and is quickly using up its feasibly exploitable hydroelectric potential, has no other alternative but atomic energy for meeting its future electric-power needs. And for reasons of national security and common sense, Brazil cannot remain dependent on outside suppliers for nuclear fuel-as the United States would like.

Carvalho pointed out that even though Brazil has not signed the Nuclear Nonproliferation Treaty (for the usual reason: opposition to the division of the world into an elite, industrialised "atomic club" and everyone else), it has submitted the agreement with West Germany to IAEA safeguard supervision. This, he said, is proof that Brazil is not going to make any bombs, adding that the world should accept the word of other countries that make similar pledges to use atomic energy only for peaceful purposes. (The IAEA Board of Governors, which met in Rio before the general meeting, approved safeguard provisions in two other major transfer-of-tech- nology nuclear agreements: the one between Canada and Spain and that between France and South Africa.)

The Nigerian delegate's contention, that developing countries are in the IAEA "to be seen but not heard" and that they are "merely tolerated" by industrialised countries, did not seem to be reflected by the vote on a proposal sponsored by Iraq to admit the Palestine Liberation Organisation to the IAEA, as an observer. Of the 71 of the 110 member countries of the agency that were present for the vote, 46 voted in favour, 21 abstained and only four (Israel, the United States, South Africa and Costa Rica) voted no.

A move led by black African countries and supported by several socialist states to expel South Africa from the IAEA, on grounds that the Pretoria government does not represent the people, did not succeed. The best these countries could do was to get a motion passed to review South Africa's permanent seat on the Board of Governors, but with no action to be taken until the 1977 IAEA meeting. It is unlikely that even this watered-down proposal will bring results, because IAEA by-laws say the permanent regional scats on the board must go to the countries in each specific area of the world that are the most advanced in nuclear technology. In Africa, there is no doubt that this is South Africa.

The effect of nuclear power stations on the environment was another topic to come up at the meeting. Eklund expressed veiled dislike for citizens' movements which have sprung up in countries such as the United States to stop further construction of nuclear reactors. The IAEA chief asserted that nuclear power plants are "friends of the environment." He said there has never been a fatal accident from nuclear causes at any of the 180 nonmilitary nuclear installations now operating around the world. In contrast, Eklund noted, there have been serious accidents at hydroelectric plants, including the bursting of dams and the consequent widespread destruction of the environment.

Debate continued at the meeting on how best to dispose of waste material from nuclear reactors, by burying it in the ground, storing it in protected containers, dispersing it into the air or dumping it into the ocean. Perhaps predictably, no consensus was reached.

\section{New directions in lobbying}

A new lobbying organisation concerned with glohal scientific environmental and social issues was established in the United States last week. Colin Norman reports from Washington

Although Washington is thick with lobbyists, public interest groups, research organisations and assorted political hucksters selling commoditics ranging from the B-1 bomber to environmental awareness, the debut last wcek of a new 'citizens lobby' deserves -and is getting-more than passing attention.

Called 'New Directions', the organisation will be devoted to raising Washington's political consciousness (or at least, the consciousness of Washington's politicians) on such international issues as arms control, population growth, environmental pollution, and the depletion of resources. It will be an unabashed lobbying enterprise, focusing its attentions on the Congress. The reason it is already attracting considerable notice is that the list of its officers and governing board reads like a Who's Who of people concerned with such matters.

Full-time President of New Directions is Dr Russell W. Petcrson, former
Governor of Delaware, who recently resigned as Chairman of the Council on Environmental Quality to head the new group. And the outfit's executive council will be chaired by Dr Margaret Mead, the well-known anthropologist who has long been active in public interest causes associated with science.

Planning for New Directions began in the Summer of 1974, when Norman Cousins, editor of Saturday Review, and Theodore M. Hesburgh, president of the University of Notre Dame, convened a small group to discuss whether such an organisation is needed and if so, what form it should take. During the past two years, the planning group has expanded to more than 100 people, including such luminaries as Robert McNamara, head of the World Bank, Kingman Brewster, President of Yale University, James Grant, president of the Overseas Development Council, Lester Brown, head of the Worldwatch Institute, and Sargent Shriver, former dircctor of the Peace Corps.

The organisation will be similar in structure to Common Cause, a lobbying group which concentrates its attentions on domestic affairs. It will be a grass-roots organisation, financed by membership fees of $\$ 25$ per year, solicitations for which will soon be made through a direct mail campaign using membership lists of sympathetic organisations. New Directions hopes to attract at least 300,000 members, a number which would give it a very sizable war chest to put its message across.

Although the general nature of that message is evident from the concerns of the people associated with New Directions, priorities and details of the organisation's objectives are now being mapped out by groups of individuals working in the general areas of arms control, poverty and the widening economic gap between rich and poor nations, environment and natural reresources, human rights, and governmental decision-making.

There are already numerous organisations active in Washington in those areas, but New Directions hopes to provide an additional function-political lobbying to get the concerns raised by various public interest organisations through to the policy makers. Few existing organisations have been able to take on such a role hecause they would lose considerable tax advantages if they were to indulge in direct lobbying activities. Essentially, they are registered as educational or research outfits. Though a recent change in the tax laws has lifted some of those restrictions, few organisations are geared up to lobby actively.

A statement put out last week by the planning committee of New Directions 
describes its relationship with existing groups. "While the work of these groups provides an essential base of information and documentation," it says, "the missing element has been a force unlimited in scope and unfettered by tax prohibitions... No organisation has set out to mobilise existing resources to take hard political action on the critical measures which must be implemented to relieve the problems which now disrupt all economies, undermine political stability, suppress human freedoms, and directly threaten human survival throughout the world. Our purpose is to build such an organisation".

The idea is that New Directions will work closely with other groups-indeed, many of them have representatives on the organisation's governing board-and draw heavily on their research and expertise. It will select issues to lobby for, try to bring together informal coalitions of groups to work on them, and serve as a coordinating centre for exchange of relevant information. But its chief role will be to draw as much attention as possible to global problems and their potential solutions, through direct lobbying with members of Congress, government officials, corporate executives and so on. It will also take its case to the news media, organise local groups, go to court when necessary, and provide direct support to candidates for political offices.

Clearly, although the organisation will derive much of its influence from its star-studded cast of backers and officials, the crucial factor in its effectiveness will be the size of its membership. Politicians tend to listen more attentively to messages delivered by groups backed by large numbers of voters or by large amounts of cash which can be used for campaign support. If New Directions can succeed in attracting hundreds of thousands of members, its voice will be heard above the general background noise in Washington.

At this point, however, it is difficult to predict whether or not the organisation can count on that level of support. The people most likely to join are probably already members of existing groups such as Common Cause, and it remains to be seen whether the depth of their concerns extends to spending another $\$ 25$. But there is at least one promising indication: the planning committee decided to go ahead only after a survey by a New York market research firm found considerable support for the goals of the organisation.

Another potential problem for the organisation is that unless it treads carefully, it may end up stepping on the toes of existing bodies which are already concerned with global problems

\section{FDA's aerosol ban}

IN a statement which caught most observers here completely by surprise, the Food and Drug Administration (FDA) announced last week that it intends to phase out the use of chlorofluoromethanes (so-called fluorocarbons) as propellants in many types of aerosol sprays. Although the statement did not say when the ban would take effect, or how it would be implemented, FDA said that it would begin by requiring warning labels to be placed on aerosols containing fluorocarbons, and that the ban would be imposed in an "orderly" manner.

The agency's action is surprising since it follows hard on the heels of a major report by a committee of the National Academy of Sciences which recommended that regulation of fluorocarbons should be delayed for up to two years to allow time for more research on the mechanism by which fluorocarbons are believed to be breaking down the ozone layer. The academy report suggested that since the rate of destruction of the ozone layer is small, a two-year delay in regulation would present little additional hazard.

Dr Alexander M. Schmidt, the Commissioner of FDA, said last week, however, that additional research would narrow the range of uncertainty in the calculations of ozone depletion but it "won't change the ultimate regulatory situation". He argued that "given the effects on human health even a $2 \%$ ozone depletion from 'unessential' uses of fluorocarbons is undesirable".

"The known fact", Schmidt said, "is that fluorocarbon propellants primarily used to dispense cosmetics are breaking down the ozone layer. Without remedy, the result could be profound adverse impact on our weather and on the incidence of skin cancer in people. It's a simple case of

- such as the United Nations Association, the Overseas Development Council and the Worldwatch Institute. A check with people from some existing groups last week, however, found little fear that New Directions would steal their thunder or interfere with their goals. In fact, most welcomed the possibility of having a heavyweight group fighting for their causes.

Some supporters of New Directions also argued last week that one of the organisation's chief assets is the fact that it is headed by Russell Peterson. A PhD chemist who worked for DuPont for 26 years, Peterson is a negligible benefit measured against possible catastrophic risk".

FDA's authority extends over foods, drugs and cosmetics. Thus, in theory, if has the power to regulate the formulation of products such as hair sprays and anti-perspirants which account for the bulk of aerosol uses of fluorocarbons. According to FDA's statement, the agency has authority over about $80 \%$ of all products now packaged in aerosol containers.

Schmidt said that FDA will publish details of its proposal to require labelling of aerosols containing fluorocarbons in mid-November, and that details of the phase-out programme will follow a few weeks later. The labelling programme itself should reduce consumption of fluorocarboncontaining products, and it will also help discourage stockpiling.

A spokesman for the DuPont company, the chief manufacturer of fluorocarbons, said last week that he was "astounded" by FDA's decision. The industry had regarded the academy's report as a victory because, in recommending a two-year delay in regulation, the academy had essentially backed the industry's argument that more research is needed to settle scientific uncertainties.

The industry is unlikely to take FDA's action lying down. Although industry spokesmen would not say last week how they expect to contest the ban, it is likely that they will ask for public hearings and, if necessary, go to court to prevent FDA putting its proposals into effect. One possible legal challenge may involve whether or not FDA has the authority under existing laws to take such action. The intensity of the industry's reaction will depend largely on how much time FDA gives it to phase out use of fluorocarbons, however, and that won't be known until towards the end of the year.

Republican who built a good reputation during his term as Governor of Delaware between 1969 and 1973. Peterson also knows his way around the Washington power structure very well, having served as chairman of the President's Council on Environmental Quality for three years. During that time, he took several independent stands, the latest of which was to call for immediate regulation of fluorocarbons in aerosol sprays. As one observer put it last week, a Republican, a former governor, and a former top adviser to the President are good credentials for a lobbyist. 